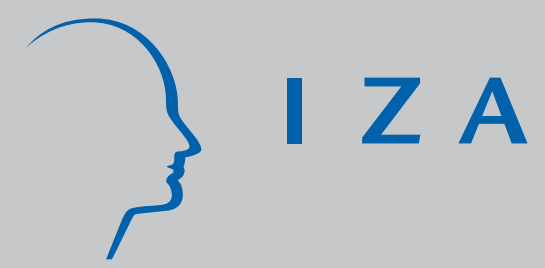

IZA DP No. 9837

Residential Segregation from Generation to Generation: Intergenerational Association in Socio-Spatial Context among Visible Minorities and the Majority Population in Metropolitan Sweden

Björn Gustafsson

Katarina Katz

Torun Österberg

March 2016 


\title{
Residential Segregation from Generation to Generation: Intergenerational Association in Socio-Spatial Context among Visible Minorities and the Majority Population in Metropolitan Sweden
}

\author{
Björn Gustafsson \\ University of Gothenburg \\ and IZA
}

Katarina Katz

Karlstad University

Torun Österberg

University of Gothenburg

Discussion Paper No. 9837

March 2016

\author{
IZA \\ P.O. Box 7240 \\ 53072 Bonn \\ Germany \\ Phone: +49-228-3894-0 \\ Fax: +49-228-3894-180 \\ E-mail: iza@iza.org
}

Any opinions expressed here are those of the author(s) and not those of IZA. Research published in this series may include views on policy, but the institute itself takes no institutional policy positions. The IZA research network is committed to the IZA Guiding Principles of Research Integrity.

The Institute for the Study of Labor (IZA) in Bonn is a local and virtual international research center and a place of communication between science, politics and business. IZA is an independent nonprofit organization supported by Deutsche Post Foundation. The center is associated with the University of Bonn and offers a stimulating research environment through its international network, workshops and conferences, data service, project support, research visits and doctoral program. IZA engages in (i) original and internationally competitive research in all fields of labor economics, (ii) development of policy concepts, and (iii) dissemination of research results and concepts to the interested public.

IZA Discussion Papers often represent preliminary work and are circulated to encourage discussion. Citation of such a paper should account for its provisional character. A revised version may be available directly from the author. 


\section{ABSTRACT \\ Residential Segregation from Generation to Generation: Intergenerational Association in Socio-Spatial Context among Visible Minorities and the Majority Population in Metropolitan Sweden}

In this paper, we investigate to what degree young adults live in neighbourhoods that are similar, in terms of relative average household income, to the neighbourhoods in which they grew up. We use regression analysis on register data for all individuals who were born in 1974 and lived in metropolitan Sweden in both 1990 and 2006. During this period, the distribution of income in Sweden became far more unequal, unemployment rose dramatically, earlier housing policies were dismantled, the share of "visible minorities" increased dramatically and residential segregation increased very considerably. We find a correlation between average neighbourhood incomes at these two points in the sample's life cycle of 0.44 , which is more than three times as high as the household income correlation. We find that half of the children of "visible minorities" grew up in the poorer quartile of neighbourhoods, and of these almost two-thirds remained in the poorest quartile of neighbourhoods as adults. Several measures indicate that intergenerational persistency in context is lower in metropolitan Sweden than was found in a similar study in the United States. However, it appears, that if visible minority individuals lived in a neighbourhood in the lowest part of the distribution in Sweden as a child, the probability that they will do so also as adults is as high as the corresponding probability for a African-American person in the US.

JEL Classification: J15, J62, R23

Keywords: Sweden, residential segregation, immigrants, intergenerational persistence

Corresponding author:

Björn Gustafsson

Department of Social Work

University of Gothenburg

P.O. Box 720

SE 40530 Gothenburg

Sweden

E-mail: Bjorn.Gustafsson@socwork.gu.se 


\section{Introduction}

This paper explores one type of intergenerational relationship that we claim has not received sufficient attention. It investigates to what degree young adults live in neighbourhoods that are similar, in terms of average household income, to the neighbourhoods in which they grew up. The degree of intergenerational persistence in (socio-spatial) context should be of interest for individual as well as societal reasons. A weak relationship is an indication of social mobility; a strong relationship leads to the opposite interpretation. Furthermore, the degree of intergenerational persistency is also an aspect of residential segregation in a society. In a society in which intergenerational persistency in context is high, most adults who live in affluent neighbourhoods have also grown up in similar areas, and most adults living in poor neighbourhoods also did so as children. If socioeconomic segregation is interwoven with ethnic division, contact between minority and majority populations becomes rarer.

Uslaner (2010) cites a common conclusion in the social capital literature, that diversity in a society reduces generalised trust. This is a trust in people in general, which is valuable for social cohesion, as opposed to merely in-group trust. Based on several UK and US studies, he challenges this view and instead concludes that it is segregation, not diversity, which hinders the interactions that boost generalised trust. He receives support from Marschall and Stolle (2004), a rare study of how neighbourhood context, inter-racial "bridging" contacts and interactions relate to generalised trust. Thus, we believe that segregation and a difference in the degree of intergenerational persistence of context according to race or ethnicity, such that minorities are "stuck in place", have the potential to foster social tension, even if the persistence is a matter of choice and even more so if it results from a restricted choice of residential locations.

In this paper, we study persons born in 1974 who grew up in metropolitan Sweden. Sweden has been known as a comparatively egalitarian country, conceived as a largely ethnically homogenous society and, therefore, one might not expect to find much intergenerational association in context. However, several processes make such a description outdated. Since the first half of the 1980s, Sweden's distribution of income has become increasingly unequal. 
Several waves of immigrants from low- and middle-income countries have entered the country at a time when unemployment increased from exceptionally low to levels similar to those of other high-income countries. Lacking a better term, we call those born in, or with parents born in, Africa, Asia, Latin America or southeastern Europe (Greece and the former Yugoslavia) "visible minorities". This term has been used by the National Board of Health and Welfare (2010) to describe such persons. To a large extent, these are groups that, in the Swedish context, could be described as "racialised". They tend to be distinguishable from most of the native population by physical appearance and by name. The parents of many immigrant children face great difficulty in finding a job. Simultaneously, much of Swedish housing policy has been dismantled and residential segregation - both social and ethnic - has become much more of an issue. As a result of those processes, a substantial number of "visible minority" children grow up in neighbourhoods seen as less attractive.

The literature on intergenerational relations in a spatial context is not large, unlike those on residential segregation or on intergenerational relationships in class, education, status or earnings. We are only aware of three previous studies of intergenerational associations in a spatial context. Two studies refer to the United States and one to Sweden, and all three report strong persistence across generations. Vartanian et al. (2007) measured neighbourhood quality in the US as a composite index of socioeconomic indicators. In a sibling fixed-effects regression, they found that growing up in the most disadvantaged neighbourhoods increased the probability of also living in such a neighbourhood as an adult, relative to others of the same ethnicity. In a study in Sweden, van Ham et al. (2014) divided neighbourhoods in the Stockholm region according to the share of persons in the neighbourhood who had low earnings in 1990, 1995, 2002 and 2008, and focus on residential histories. They find that those who live in areas with a high level of poverty as children tend to also do so later in life. By also showing how income differences between the poorer and more affluent neighbourhoods have developed over time, we can include another aspect of segregation in addition to those considered by van Ham et al. (2014). Sharkey's (2008; 2013) studies of intergenerational persistence in racial and social segregation are the only previous ones that focus on average disposable income in the neighbourhood in which a person lives as a child 
and as an adult. Sharkey's statistical analysis was inspired by the literature on intergenerational association in earnings. ${ }^{1}$

Since we followed Sharkey in the statistical analysis, our results for Sweden can be put in perspective by those reported for the United States, despite differences in data and definitions. As previous studies (cited in Section 6) indicate that the intergenerational relationship in earnings is stronger in the United States, we ask whether the same applies to intergenerational associations in a spatial context. We also ask to what extent visible minorities in Sweden can be said to be "stuck in place" in a manner analogous to what Sharkey found for African-Americans in the United States.

\section{Neighbourhoods and intergenerational association in context}

A person's well-being is not defined only by earnings, income, occupation and class; their place of residence is also of major importance. Obviously, the "attractiveness" or "quality" of a neighbourhood has many facets and dimensions. For our quantitative analysis we operationalise "spatial context" as the average household income in the neighbourhood in which the person lives. In a market economy, average household income in a neighbourhood provides an instructive, albeit imperfect, indicator of how highly a neighbourhood ranks. High household income as well as wealth makes it easier to obtain a residence located in an attractive neighbourhood. Conversely, those with limited economic resources and those who do not have a useful social network, as well as minorities discriminated against in the housing

\footnotetext{
${ }^{1}$ For recent surveys of this literature, see Blanden (2013) and Jäntti and Jenkins (2015). As discussed by Roemer (2004), income or earnings in the household in which a person grew up can affect the formation of preferences or effort, and therefore intergenerational measures of association may not be an accurate measure of inequality of opportunity. A similar argument can be applied to intergenerational relations in context: people's preferences for where they live as adults can be affected by where they grew up.
} 
market, have more restricted opportunities for residential choice. However, to change one's place of residence involves transaction costs - economic, social and psychological - and households tend to remain in the same residence for a number of years, even though household income may have changed substantially. Due to this, and a preference for living close to relatives and where one grew up (see Hedman, 2013), as well as other circumstances (the household's possession of wealth, social capital and also market regulations), the relationship between present household income and neighbourhood average income is far from perfect.

In recent decades, major conurbations in many European countries have seen the growth of neighbourhoods with high concentrations of joblessness, low incomes and poor educational outcomes for youth. Such neighbourhoods have been described as "neighbourhoods of relegation... within which social isolation and alienation feed upon each other as the chasm between those consigned there and the broader society deepens" (Wacquant, 2008:261). These European "outer cities" have not been formed by the same policies of abandonment as the US ghettos (Wacquant, 2008; Sharkey, 2013). Yet, although European states, in particular the Nordic welfare states, may be said to have partly resisted this process of "advanced marginalisation", a sense of frustration, of being locked without possibility of exit into a geographical space that is stigmatised, has also been expressed by young people in Swedish studies (see for example Beach and Sernhede, 2011).

This development is one reason why many scholars have investigated the possible existence and magnitude of neighbourhood effects on various types of behaviour and opportunities, predominately for younger persons - in education, housing, employment and social norms. The literature analysing neighbourhood effects and the methodological issue involved is vast. For an introduction, we refer the reader to Galster (2008), and for a survey of Swedish studies, to Andersson (2007).

We expected to find a positive correlation in average neighbourhood income across generations for several reasons; the intergenerational transmission of education and its influence on labour market outcomes is an obvious one. Second, people, in particular 
households with young children, may value being near friends and relatives. Parents with resources, who can help their children find a home of their own or help them to buy it, tend to live in more affluent neighbourhoods. In some, probably far fewer, cases, there is even a direct intergenerational transmission of housing (Öst, 2012). Beyond parental characteristics, neighbourhoods may be important for several reasons. Ethnicity or race may be correlated with neighbourhood average income due to discrimination, which excludes people belonging to certain identifiable groups from housing in attractive areas. Correspondence testing has demonstrated discrimination against persons with Muslim-sounding names in the Swedish housing market (Ahmed and Hammarstedt 2008; Ahmed et al. 2010; Carlsson and Eriksson, 2014). Schools in disadvantaged neighbourhoods may be less able to provide a good quality of education. Networks and contacts, instrumental in finding and obtaining attractive housing, are scarcer in low-income neighbourhoods and, in general, less available to children of immigrants with a limited period of residence in Sweden.

The aim of our study was to investigate the relationship between average household income in the neighbourhoods in which individuals lived when aged 16 and aged 32 years old.With the available data, this is as close as we can get to observing parents and children at a similar phase of their life cycle. A somewhat higher age than 32 may have been ideal, but at 32 we can expect most households to be relatively settled. By this age, almost all young adults in Sweden have left their parental home, a large majority have completed their formal education and most have also found a job. Many have also found a partner and a substantial number have become parents. ${ }^{2}$ After 30 years of age, changes of address in a given year become much less frequent than at 20-30 years of age (Statistics Sweden, 2015b). The calculations

\footnotetext{
${ }^{2}$ More than half of men aged 22 and women aged 21 were registered as having moved from the parental home during the relevant time period. An additional number may have moved out but not changed their registered address (Statistics Sweden, 2015a). The average age of first-time mothers in 2006 was 29 years old, and that of first-time fathers was 31 years old (Statistics Sweden, 2007).
} 
we have made for those individuals in metropolitan regions who were 32 years old in 2004, i.e. two years earlier than the cohort we study, show that 30 per cent changed address during the following two years, but only 6 per cent to a neighbourhood with significantly different socio-economic characteristics from the one they left. Van Ham et al. (2014) describe a pattern according to which many young adults move from the parental home to a neighbourhood with lower income, then to a more well-off one when they have finished their education and/or start a family, and eventually settle in a neighbourhood in which economic circumstances are relatively similar to those where they grew up.

\section{The changed Swedish scene}

As mentioned, income dispersion in Sweden has increased profoundly (Fritzell et al. 2014). Several interrelated factors have contributed to this: increased earnings and wage inequality (Domeij and Flodén, 2010), the increased importance of capital gains and other types of capital income concentrated in the upper part of the income distribution (Roine and Waldenström, 2012) and a decrease in tax progressivity and in taxation for most capital income earners, following tax reforms in the early 1990s.

For several decades, Sweden was known to have low open unemployment. This changed at the beginning of the 1990s, when the downturn in the world economy hit Sweden harder than many other OECD countries. Since then, there have also been many changes in public policy. For example, much of the previously existing social housing policy has been dismantled (see Hedin et al, 2012 and Andersson and Magnusson Turner, 2014). Sweden has also become a more ethnically diverse society due to immigration. Many immigrants who came during the recent decades arrived for political reasons or family reunification, many of them from Africa, Asia and Latin America. The data source we describe in the next section shows that in 2006 as many as 17 per cent of persons aged 16 years old and living in the metropolitan areas of Sweden belonged to what we term "visible minorities". Most of these had spent the greater part of their lives in Sweden. 
A large number of studies have shown that immigrants to Sweden who are visibly different from the majority by physical appearance and name fare considerably worse than the native population. The gap in employment rates between immigrants and natives in Sweden is one of the largest among rich countries (OECD 2012, p 90) and there is also a considerable gap between income and earnings (Schröder, 2007). The visible minority part of our sample were either born in Sweden or immigrated as children. To have parents born in southern Europe or non-European countries is associated with negative differentials relative to native Swedes in terms of employment and earnings and wage rates (Rooth and Ekberg, 2003; Katz and Österberg, 2013). In particular, young people with immigrant backgrounds are disadvantaged by a lack of those informal networks that are essential for finding a job, and for improving the quality of the job found (Behtoui, 2004). Such contacts are less likely to be found through neighbours and school friends in neighbourhoods with low incomes and low levels of employment. Thus, a deprived neighbourhood can contribute to cementing the disadvantages of youngsters who grow up there, in particular those from an immigrant background.

Lack of integration into the Swedish labour market has increased the gap in disposable household income between natives and visible minorities, and this is one important reason why visible minorities are often concentrated in low income neighbourhoods that contain a low share of the majority population. As shown by several studies, Sweden's urban areas have become economically and ethnically more segregated than previously (see Biterman et al., 2008; Bråmå, 2008 and Scarpa, 2015). At the political level, the government formalised a metropolitan policy consisting of programmes aimed at supporting disadvantaged areas in 1998 (see Ministry of Finance, 1998). However, policy initiatives have not prevented urban 
unrest and violence from taking place in disadvantaged immigrant-dense neighbourhoods. ${ }^{3}$ It remains to be seen whether the exceptionally high levels of generalised trust for which the Nordic countries have been noted (Delhey and Newton, 2004) will remain, despite increased income disparities and residential segregation.

\section{Data and definitions}

We studied the three largest conurbations in Sweden in which residential segregation can be supposed to be most pronounced, and for which neighbourhood coding is available. These three metropolitan regions include more than a third of the country's total population, 3.3 out of approximately nine million. The most populous region includes the capital, Stockholm, and 23 neighbouring municipalities. The second largest is the Gothenburg metropolitan region, including eight municipalities, while the Malmö region includes nine.

We worked with data from the LISA database (Longitudinell integrationsdatabas för Sjukförsäkrings- och Arbetsmarknadsstudier), plus information on each individual's address and matching neighbourhood codes, see Statistics Sweden (2011). The population studied consists of all individuals who were born in 1974 and who lived in an urbanised neighbourhood of one of the three metropolitan areas in 1990 and 2006. We also used data on their parents and all individuals in the neighbourhoods in which they lived. ${ }^{4}$

\footnotetext{
${ }^{3}$ See Malmberg et al. (2013). In the spring of 2013, the news of rioting in some Swedish suburbs made headlines in international media such as Le Monde, Financial Times, Deutsche Welle and Washington Post. In 2015 , deadly shootings by criminals caused great concern.

${ }^{4}$ Our database included information about individuals aged 16 and older and neighbourhood coding from 1990 to 2006. We therefore chose the cohort born in 1974, which we could follow for the longest period of time.
} 
Different definitions of "neighbourhood" have been used in research on Sweden. The one we applied was developed to map residential segregation in metropolitan Sweden, and is not an administrative category. ${ }^{5}$ It was documented in Biterman and Franzén (2007). A neighbourhood is defined as a population area that:

- Is demarcated by natural borders (major streets, green areas, etc.).

- Corresponds to a city district or a residential area.

- Has a number of inhabitants large enough to provide the basis for certain private or public services.

- Can be supposed to be defined as a neighbourhood by its inhabitants. ${ }^{6}$

The neighbourhoods we study had the same borders in 1990 and 2006. Most had a population of between 4,000 and 10,000 inhabitants. In total, 24,904 persons born in 1974 were registered in 1990. We excluded rural neighbourhoods on the outskirts of suburban municipalities, as well as neighbourhoods with fewer than 500 inhabitants. We followed the 78 per cent $(19,445$ persons; 17,891 belonging to the majority and 1,554 classified as visible minorities) who still lived in one of the metropolitan areas in 2006. Thus, we followed persons who had moved from one metropolitan region to another, but not those who had moved to a place outside of these metropolitan areas (17 per cent of the original population). In 2006, about five per cent of the original population from 1990 had either emigrated or died.

\footnotetext{
${ }^{5}$ Some Swedish studies use the Small Areas for Market Statistics (SAMS). The disadvantage of these is that they are not uniform for the three regions studied (see Amcoff, 2012). Others, for example van Ham et al. (2014), use bespoke measures, which, unlike ours, do not consider the physical characteristics of, for example, buildings and roads when defining what constitutes a neighborhood.
}

\footnotetext{
${ }^{6}$ To achieve this, extensive consultation was undertaken with locally active persons such as teachers and social workers in each area.
} 
From the data, we also calculated neighbourhood characteristics based on all individuals in the specific neighbourhood in 1990. Several variables show the demographic composition in the neighbourhood in 1990. For each person in the neighbourhood, we calculated average disposable household income in 1990 and 2006 by adding earnings, capital income, income from capital gains and public transfers, and subtracting income taxes paid for all household members and adjusting with the use of a frequently used equivalence scale. ${ }^{7}$ The income derived in this way is assigned to each member of the household. Thus, average neighbourhood household income is the average disposable income of all individuals living in the neighbourhood, irrespective of age.

\section{Measuring the degree of intergenerational persistence in context}

/Figure 1 about here/

Figure 1 shows mean neighbourhood incomes in 1990 and 2006, arranged from the lowest to the highest values for the three metropolitan regions combined, in constant prices. The distribution was remarkably even in 1990, with a Gini coefficient of only 0.05. The Gini coefficient is a frequently used measure of inequality which ranges from 0 (no inequality) to 1 (maximal inequality). With the exception of the very lowest part of the distribution, in each percentile the average neighbourhood income in 2006 is higher than in 1990 and the graph has a steeper slope. While average neighbourhood income for the poorest decile (tenth) grew by only 1 per cent per annum from 1990 to 2006, growth was between 2 and 3 per cent per

7 This scale is used by the National Board of Health and Welfare. It starts at 1.16 for the first adult in the household, is set to 1.92 for two adults, and adds another $0.56,0.66$ and 0.76 for each child aged $0-3,4-10$ and 11-17, respectively. 
annum for most percentiles and over 6 per cent per annum for the top decile. Thus, inequality in the distribution of neighbourhood average income increased rapidly; the Gini-coefficient for mean neighbourhood income had risen to 0.13 in 2006 . Hence, we can confirm that residential income segregation in metropolitan Sweden has increased rather sharply, albeit from a low level.

\section{/Table 1 about here/}

Table 1 contains descriptive statistics for the total sample and for the subsamples of visible minorities and the majority. "Majority" for our purposes means "not visible minority" as defined above. One in six persons in the majority population lived in the same neighbourhood at age 32 as at age 16, as did as many as one in four of the visible minority population. On average, the cohort under study experienced an increase in household income between 1990 (when the young persons lived with their parents or parent) and 2006 of almost 50 per cent in constant prices. Visible minority households had 30 per cent lower disposable income than majority households in 1990, and 22 per cent lower disposable income in 2006. Thus, the income gap narrowed across the generations, but only by about a quarter. The visible minority and the majority parental households differ in certain respects. Our data show that the former have a larger number of children and their level of education is lower, and Table 1 shows that their disposable income is nearly 10 per cent lower.

We investigated the relationship between neighbourhood average household incomes 2006 and 1990 first by estimating intergenerational neighbourhood income elasticities and correlations, and second by calculating transition matrices. The elasticities, shown as $\beta$ in equation (1), indicate the expected difference, in per cent, between the average neighbourhood income in 2006 of two persons who in 1990 lived in neighbourhoods whose average incomes differed by one per cent. It is estimated as the regression coefficient when the logarithm of the dependent variable is regressed on the logarithm of the covariate. We also calculated the correlation between the average income in the neighbourhood where person $i$ lived in $2006\left(\mathrm{Y}_{2006 \mathrm{i}}\right)$ and in the neighbourhood where they lived in $1990\left(\mathrm{Y}_{1990 \mathrm{i}}\right)$, as shown in equation (2). By definition, a correlation coefficient takes values from -1 , 
indicating a perfect negative relationship, to +1 , indicating a perfect positive relationship, while the value 0 means no relationship.

The correlation is equal to the elasticity multiplied by the ratio between the variances of $\mathrm{Y}_{1990}$ and $Y_{2006}$, respectively $\left(\sigma_{1990}\right.$ and $\left.\sigma_{2006}\right)$. As the dispersion of neighbourhood average income in 2006 was much larger than in 1990, the correlation coefficient will be smaller than the elasticity. We also made a simulation which assumed that all young adults had remained in the same neighbourhood in which they grew up, as a baseline against which to compare the actual intergenerational neighbourhood elasticity.

A person who grew up in a low income neighbourhood may remain there, or move back to it, because they do not have the option of moving to one which is better off, or preferences to be be close to family and friends. Therefore, as a sensitivity check, we also made separate estimates of the elasticity and correlation for a dataset consisting of persons who did not live in the same neighbourhood in 2006 as in 1990. As another comparison, we estimated intergenerational income elasticities at the household, instead of the neighbourhood level.

(1) $\ln Y_{2006 i}=\alpha+\beta \ln Y_{1990 i}+e_{i}$

(2) $\rho=\beta\left(\frac{\widehat{\sigma}_{1990}}{\widehat{\sigma}_{2006}}\right)$

\section{Persistence of neighbourhood economic status}

/ Table 2 about here/

The top panel of Table 2 shows intergenerational income elasticities and correlation coefficients for neighbourhood average disposable income for the pooled samples, and for each of the two sub-samples. The second panel shows the corresponding numbers derived from the analysis of household income. As expected, the elasticities are much larger than the correlation coefficients. The elasticity for neighbourhood average income estimated for our 
entire sample is 1.03 , much higher than the elasticity for household income of only 0.24 . Such a high elasticity for neighbourhood average income implies the same expected difference in the logarithm of neighbourhood average income for persons when aged 32 as when aged 16. Another way of expressing this is to say that in our sample there was no convergence in average neighbourhood income from age 16 (when they lived with their parents) to age 32 . In contrast, the difference in household income was reduced by as much as three quarters during the same period: a strong convergence. The corresponding correlation coefficients are 0.44 and 0.13 . The third panel shows what the measures of association would have been if all young adults had remained in the neighbourhood in which they grew up. If this had been the case, and the dispersion in neighbourhood income had remained constant, the elasticity would have been equal to 1 . But the simulation shows an elasticity of 2.33 income disparities between neighbourhoods had increased so much that, on average, the difference between the incomes in two persons' neighbourhoods would have more than doubled if they did not change neighbourhood.

To what extent is the elasticity reported in the first panel of Table 2 due to the fact that some young adults live in the same neighbourhood in 2006 as in 1990? To answer this question, we repeated the estimates but omitted from the analysis persons who lived in the same neighbourhood in both years. The coefficients and correlations reported in the fourth panel of Table 2 are lower than those reported in the first panel, but the difference is not dramatic. From this, it follows that wanting to live in the same neighbourhood is not a major mechanism behind the strong elasticities and correlations we found for the entire sample. Looking at the sub-samples of the majority and visible minorities, we find association in context across generations of a similar order of magnitude. 


\section{/Table 3 about here/}

Another way of measuring intergenerational association is through mobility matrices. Table 3 reports outflow values for each of the two sub-populations, where the sample of persons has been divided into quartiles (equally-sized classes) by neighbourhood average income as observed in each year. ${ }^{8}$ As can be seen, there are large differences between the two subpopulations. Among visible minority persons, of the quarter who grew up in the poorest neighbourhoods in metropolitan Sweden, as many as 61 per cent lived in the lowest quarter of neighbourhood when they were aged 32, compared to only 35 per cent among those in the majority population who lived in the same neighbourhood category as teenagers. The proportion of downwardly mobile persons from the highest to the lowest quartile of neighbourhoods was 22 per cent among visible minorities, but only 8 per cent in the majority population. By contrast, out of those who lived in neighbourhoods in the top quarter of the distribution as teenagers, the proportion that also did so as adults is almost identical for the two sub-samples — slightly less than half.

/Table 4 about here/

In Table 4, we present the intergenerational relationship in context by reporting cell percentages for the two populations. Thus, the numbers in each panel of the table add up to 100. Again, the differences between the two sub-populations are clearly visible. As many as 34 per cent of the visible minority population in Sweden were in the lowest quartile of the distribution both as teenagers and as adults, while the corresponding proportion in the

\footnotetext{
${ }^{8}$ As neighbourhood income grew between 1990 and 2006, the boundaries between the quartiles, measured in real income, differ between the years.
} 
majority population was only 7 per cent. Visible minorities are thus "stuck in place" for two generations to a much larger extent than the majority. ${ }^{9}$

\section{A comparison with the US}

How do the results from our study of metropolitan Sweden compare with those Sharkey (2008) obtained for the United States, using somewhat different definitions? ${ }^{10}$ As is well known, there are large social and institutional differences between Sweden and the United States, which can be expected to lead to differences in results. For example, Sweden has more ambitious welfare programmes, free tuition at all levels of education and also higher taxes. Many empirical studies suggest that the distribution of household income is more equal in Sweden than in the United States (see, for example, Brandolini and Smeeding, 2009). All available evidence indicates greater intergenerational income mobility in Sweden than in the US (see Björklund and Jäntti, 1997, and Jäntti et al., 2006). The US has a disadvantaged African-American population, many of whom are descendants of persons who were originally brought to the country by force. African-Americans have lived in the US for

\footnotetext{
${ }^{9}$ Following Sharkey (2008), we also studied to what extent the relationship between neighbourhood average incomes for the two generations remains, if potentially mediating variables are added to the intergenerational model in equation (1). We included both a number of covariates measured at the neighbourhood level in 1990 and variables referring to the household in which the young adult grew up, as well as a dummy for gender. We found that observed characteristics do not, in a statistical sense, explain why neighbourhood average income is so strongly associated across generations. This finding echoes what Sharkey reports from a similar exercise for the US.

${ }^{10}$ Sharkey (2008) worked with data for the entire US, whereas we concentrated on metropolitan Sweden. We used a definition of "neighbourhood" designed for research; Sharkey used census tracts. We had register data on 19,445 individuals belonging to a single birth cohort and observed these first when aged 16, and again when aged 32. Sharkey studied a sample of 4,464 persons when aged 18 and younger, and again when aged 26 and older.
} 
centuries, while the population we define as visible minorities in Sweden is much more recent.

The intergenerational correlation of context of 0.64 reported by Sharkey (2008) for the US is so much higher than the 0.44 we found for metropolitan Sweden that it appears difficult to maintain that the difference is only caused by differences in how the studies were designed. Consistent with this, we can report that a lower proportion of the disadvantaged population in Sweden, the visible minorities, remained in the lowest quartile from one generation to the next. For Sweden the proportion was one-third, while Sharkey reported that 52 per cent of African-Americans in the United States remained in the lowest quartile for two generations. However, the 16 per cent of all majority persons who remained in the top quartile for two generations in Sweden is similar to the 18 per cent Sharkey reported for whites in the United States.

\section{/Table 5 about here/}

Quartiles at the bottom and top of the income distribution are rather broad income classes and there may be large differences within each. We, therefore, split the dataset into deciles and reported the results for the top and bottom deciles in Table 5, together with the corresponding results from Sharkey. Note the striking similarities between Sweden and the US with regard to the bottom decile of neighbourhoods. Slightly less than half of the visible minorities who grew up in the bottom decile of neighbourhoods in Sweden lived in a similar neighbourhood at age 32, while among African-Americans in the US the share is slightly above half. This can be contrasted with the majority population in Sweden, and whites in the US, who started off from the same position. Among them, 22 per cent in Sweden and 19 per cent in the US also lived in such a neighbourhood as adults.

Note, however, that a larger proportion of all African-Americans in the US compared to the visible minorities in metropolitan Sweden grew up in the poorest decile. Thus, while 25 per cent of all African-Americans in the US lived in the poorest decile for two generations, the corresponding number for visible minorities in Sweden was 19 per cent. Note also that very 
small percentages of the majority population in Sweden and of whites in the US spent two generations in the poorest decile of neighbourhoods. Table 5 also indicates that intergenerational persistence in spatial context at the top of the distribution is higher among whites in the US sample than among the majority in the Swedish sample.

The comparison between Sweden and US has shown both similarities and differences. In both countries, minorities are "stuck in place", meaning that a relatively large percentage live in underprivileged neighbourhoods during both childhood and young adulthood. The overall degree of intergenerational persistence in context appears to be larger in the US than in Sweden, which is consistent with findings from cross-country comparisons in intergenerational individual earnings.

\section{Conclusions}

We claim that it is of interest to study intergenerational links, not only in status, class and income, but also in spatial context, that is, the neighbourhood in which the person lives. Therefore, in this study of metropolitan Sweden, we have related average neighbourhood income for persons born in 1974 at age 32, to average neighbourhood income when they were aged 16. During the period between 1990 and 2006, the distribution of income became more unequal, unemployment quadrupled, much of the previous housing policy was dismantled, the percentage of visible minorities increased dramatically and residential segregation increased very considerably. Among visible minorities, many experienced difficulties finding a job. Our study was based on register data for 19,445 individuals and we used a definition of "neighbourhood" that has been constructed for research purposes. Our results were compared with similar ones previously reported for the United States.

One of our key conclusions is that the relationship between the average incomes of the neighbourhoods in which a person lives when aged 32 and aged 16 is strong. The correlation between neighbourhood incomes in these two years was 0.44 , which is more than three times greater than the correlation between household incomes. The intergenerational elasticity for context was high, at 1.03 . This means that our sample experienced no convergence in average 
neighbourhood income from age 16 (when they lived with their parents) to age 32 . This should be understood against a background of rapidly increasing dispersion in average neighbourhood incomes in metropolitan Sweden between 1990 and 2006. We also found that most of the strength of intergenerational neighbourhood relationships remain strong, even when we exclude individuals who remained in the same neighbourhood.

Another key finding is that of large differences between visible minorities and the majority population in terms of the percentage of each that both grew up in underprivileged neighbourhoods and lived in such neighbourhoods as adults. Slightly more than half of the children of "visible minorities" grew up in the poorest quartile of neighbourhoods in metropolitan Sweden, and as many as 61 per cent of these remained in the poorest quartiles of neighbourhoods as adults. Thus, it appears that Sweden's visible minorities are to a large degree "stuck in place". If a person belongs to the majority population, the probability of leaving a neighbourhood with a low average household income is much higher.

Wacquant (2008) concludes that the African American "hyperghetto" and the marginalised neighbourhoods in Europe have some similarities, but also large differences in degrees of deprivation and historical, political and sociological contexts. Measured by the intergenerational income correlation, as well as by mobility matrices, the intergenerational persistency in a spatial context appears to be lower in metropolitan Sweden than in the United States. However, there is also a similarity between the two countries. The probability of leaving the decile of neighbourhoods with the lowest average incomes is nearly as low for visible minorities in Sweden as it is for African American people in the United States.

To the best of our knowledge, there have only been three previous studies on the degree of intergenerational relationship in spatial context and we hope that our results may stimulate more research, using the same or other kinds of framework. There appears to be good reason to undertake studies for countries other than Sweden and the United States, as well as to make cross-country comparisons. Younger cohorts can be investigated in order to find out if the intergenerational relationship in a spatial context has changed. Furthermore, there is 
reason to follow the cohort studied here later in life, in order to find out how the intergenerational relationship in a spatial context develops over their life cycles. 


\section{References}

Ahmed, A. and Hammarstedt, (2008) "Discrimination in the Rental Housing Market: A Field Experiment on the Internet", Journal of Urban Economics, 64, 362-372.

Ahmed, A., Andersson, L. and Hammarstedt, M. (2010) "Can Discrimination in the Housing Market be Reduced by Increasing the Information about the Applicants?", Land Economics, 86, (1), 79-90.

Amcoff, J. (2012) "Hur fungerar SAMS-områdena i studier av grannskapseffekter? En studie av SAMS-områdenas homogenitet", (How well does SAMS work in studies of neighbourhood effects?"), Socialvetenskaplig Tidskrift, 19, 93-115.

Andersson, R. (2007) "Ethnic Residental Segregation and Integration Processes in Sweden" pages in Schönwälder, E. (Ed) Residental Segregation and Integration of Immigrants: Britain, the Netherlands and Sweden", Berlin: AKI Wissenchaftzentrum Berlin fuer Sozialforschung $\mathrm{Nr} \quad \mathrm{SP} \quad 10 \quad 2007-602 \quad$ available at http://www.econstor.eu/obitstream/10419/49762/1/54626994X.pdf\#page=63

Downloaded 20150818.

Andersson, R. and Magnusson Turner, L. (2014) "Segregation, gentrification, and residualisation. From public housing to market-driven housing allocation in inner-city Stockholm", International Journal of Housing Policy, 14, 3 - 29.

Beach, D. and Sernhede, O. (2011). From learning to labour to learning for marginality: School segregation and marginalisation in Swedish suburbs. British Journal of Sociology of Education, 32, 257-274.

Behtoui, A. (2004). "Unequal Opportunities for Young People with Immigrant Backgrounds in the Swedish Labour Market " Labour 18 (4): 633-660

Biterman, D. and Franzén, E. (2007). "Residential Segregation (Chapter 6)" in International Journal of Social Welfare, 16, Supplement 1, 127-162.

Biterman, D.; Gustafsson, B. ; Österberg, T. (2008). Economic and Ethnic Polarisation among Children in Sweden's Three Metropolitan Areas. Schmollers Jahrbuch. Journal of Applied Social Science Studies. 128 (1) s. 121 - 152.

Björklund, A. and Jäntti, M. (1997) "Intergenerational Income Mobility in Sweden Compared to the United States", American Economic Review, 87 (5), 1009 - 1018.

Blanden, J. (2013) "Cross-country Rankings of Intergenerational Mobility: A Comparison of Approaches from Economics and Sociology", Journal of Economic Surveys, 23, 38-73.

Brandolini, A. and Smeeding. T. (2009) "Income Inequality in Richer and OECD Countries", in Salverda, W., Nolan, B. and Smeeding, T. (Eds) (2009) The Oxford Handbook of Economic Inequality, Oxford: Oxford University Press. 
Bråmå, ̊̊ (2008), "Dynamics of Ethnic Residential Segregation in Göteborg, Sweden, 1995 2000", Population, Space and Place, 14, $101-117$.

Carlsson, M. and Eriksson, J. (2014) "Discrimination in the Rental Market for Apartments", Journal of Housing Studies, 23, $41-54$.

Delhey, J. and Newton, K. (2004) "Social trust: Global pattern or nordic exceptionalism?” WZB Discussion Paper SP I 2004-202, WZB, Berlin

Domeij, D. and Flodén, M. (2010) "Inequality Trends in Sweden 1978 - 2004", Review of Economic Dynamics, 13, 179 - 208.

Fritzell, J., Bacchus Hertzman, J., Bäckman, O., Borg, I., Ferrarini, T. and Nelson, K. (2014) "Sweden: Increasing Income Inequality and Changing Social Relations" in Nolan, B. et al (Eds) Changing Inequalities and Social Implications in Rich Countries. Thirty Countries' Experiences, Oxford: Oxford University Press.

Galster, G. (2008) "Quantifying the Effects of Neighbourhood on Individuals: Challenges, Alternative Approaches, and Promising Directions", Schmollers Jahrbuch. Journal of Applied Social Sciences Studies, 128, 7 - 48.

Hedin, K., Clark, E., Lundholm, E and Malmberg, G. (2012) "Neoliberalization of Housing in Sweden: Gentrification, Filtering, and Social Polarization", Annals of the Association of American Geographers, 102, 443-463.

van Ham, M., Hedman, L., Manley, D. and Coulter, R. (2014) "Intergenerational Transmission of Neighbourhood Poverty in Sweden: An Innovative Analysis of Individual Neighbourhood Histories", Transactions of the Institute of British Geographers, 39 (4), 402414.

Hedman, L. (2013) "Moving Near Family? The Influence of Extended Family on Neighbourhood Choice in an Intra-urban Context", Population, Space and Place, 19, 32-45.

Jäntti, M., Bratsberg, B., Röed, K., Raaum, O., Naylor, R., Österbacka, E., Björklund, A. and Eriksson, T. (2006) "American Exceptionalism in a New Light: A Comparison of Intergenerational Earnings Mobility in the Nordic Countries, the United Kingdom and the United States", IZA Discussion Paper No. 1938.

Jäntti, M. and Jenkins, S. P. (2015) "Income Mobility", in Atkinson, A. and Bourguignon, F. (Eds) Handbook of Income Distribution,, Volume 2. Amsterdam: Elsevier.

Katz, K. and Österberg, T. (2013) Wages of childhood immigrants in Sweden - education, returns to education and overeducation. IFAU Working Paper 2013:8. Uppsala. 
Malmberg, B., Anderson, E. and Öst, J. (2013) "Segregation and Urban Unrest in Sweden", Urban Geography, 34 (7), 1031 - 1046.

Marschall, M. and Stolle, D. (2004) "Race and the city: Neighbourhood Context and the development of generalized trust", Political Behavior, 26:2, 125-153

Ministry of Finace (1998) "Utveckling och rättvisa - En politik för storstaden på 2000-talet”. Prop 1997/98:165. Available at:

http://www.regeringen.se/contentassets/805a982b8ffd4327b4027a64075e1f19/-utvecklingoch-rattvisa---en-politik-for-storstaden-pa-2000-talet Downloaded 20151103.

National Board of Health and Welfare (2010) Social Rapport 2010, Stockholm.

Organisation of Economic Co-operation and Development (2012) Settling In: OECD Indicators of Immigrant Integration 2012. Paris.

Öst, C. E. (2012) "Parental Wealth and First-time Homeownership: A Cohort Study of Family Background and Young Adults' Housing Situation in Sweden", Urban Studies, 49, 2137-2152.

Roemer, J. E. (2004) "Equal Opportunities and Intergenerational Mobility: Going Beyond Intergenerational Transition Matrices" in Corak, M. (Ed) Generational Income Mobility In North America and the United States, Cambridge: Cambridge University Press.

Roine, J. and Waldenström, D. (2012) "On the Role of Capital Gains in Swedish Income Inequality", Review of Income and Wealth, 58, 569-587.

Rooth, D. and Ekberg, J. (2003) "Unemployment and Earnings for Second Generation Immigrants in Sweden: Ethnic Background and Parent Composition " Journal of Population Economics 16 (4): 787-814.

Schröder, L. (2007) "From Problematic Objects to Resourceful Subjects: An Overview of Immigrant-Native Labour Market Gaps from a Policy Perspective", $\underline{\text { Swedish Economic }}$ Policy Review 14 (1), 7-31.

Scarpa, S. (2015) "The Impact of Income Inequality on Economic Segregation: The Case of Malmö, 1991-2010.”, Urban Studies, 52, 906 - 922.

Sharkey, P. (2008) "The Intergenerational Transmission of Context", American Journal of Sociology, 113, 931-69.

Sharkey, P. (2013) Stuck in Place. Urban Neighborhoods and the End of Progress toward Racial Equality, Chicago: Chicago University Press. 
Statistics Sweden (2007) http://www.scb.se/sv_/Hitta-statistik/Statistik-efteramne/Befolkning/Befolkningenssammansattning/Befolkningsstatistik/25788/25795/Behallare -for-Press/Pappa-tre-ar-aldre-an-mamma/. Accessed 20151029

Statistics Sweden (2011) Longitudinell integrationsdatabas för Sjukförsäkrings- och Arbetsmarknadsstudier (LISA) 1990-2009, (Integrated database for labour market reserach) Series Background Facts Labour and Education Statistics 2011:4. Örebro.

Statistics Sweden (2015a) På egna ben. En beskrivning av ungas flytt från föräldrahemmet. Demografiska Rapporter, Rapport 2015:3, Statistics Sweden. Stockholm.

Statistics Sweden

http://www.scb.se/statistik/_publikationer/BE0101_2006A01_BR_11_BE0107TAB.pdf. Accessed 20151029

Uslaner, E. (2010) "Segregation, mistrust and minorities", Ethnicities, 10:4, 415-434

Vartanian, T., Walker Buck, P., Gleason, P. (2007), Intergenerational Neighborhood-Type Mobility: Examining Differences between Blacks and Whites", Housing Studies, 22, 833856.

Wacquant, L. (2008). Urban Outcasts. A Comparative Sociology of Advanced Marginality. Cambridge: Policy Press. 
Figure 1.

Mean neighbourhood income by percentiles 1990 and 2006

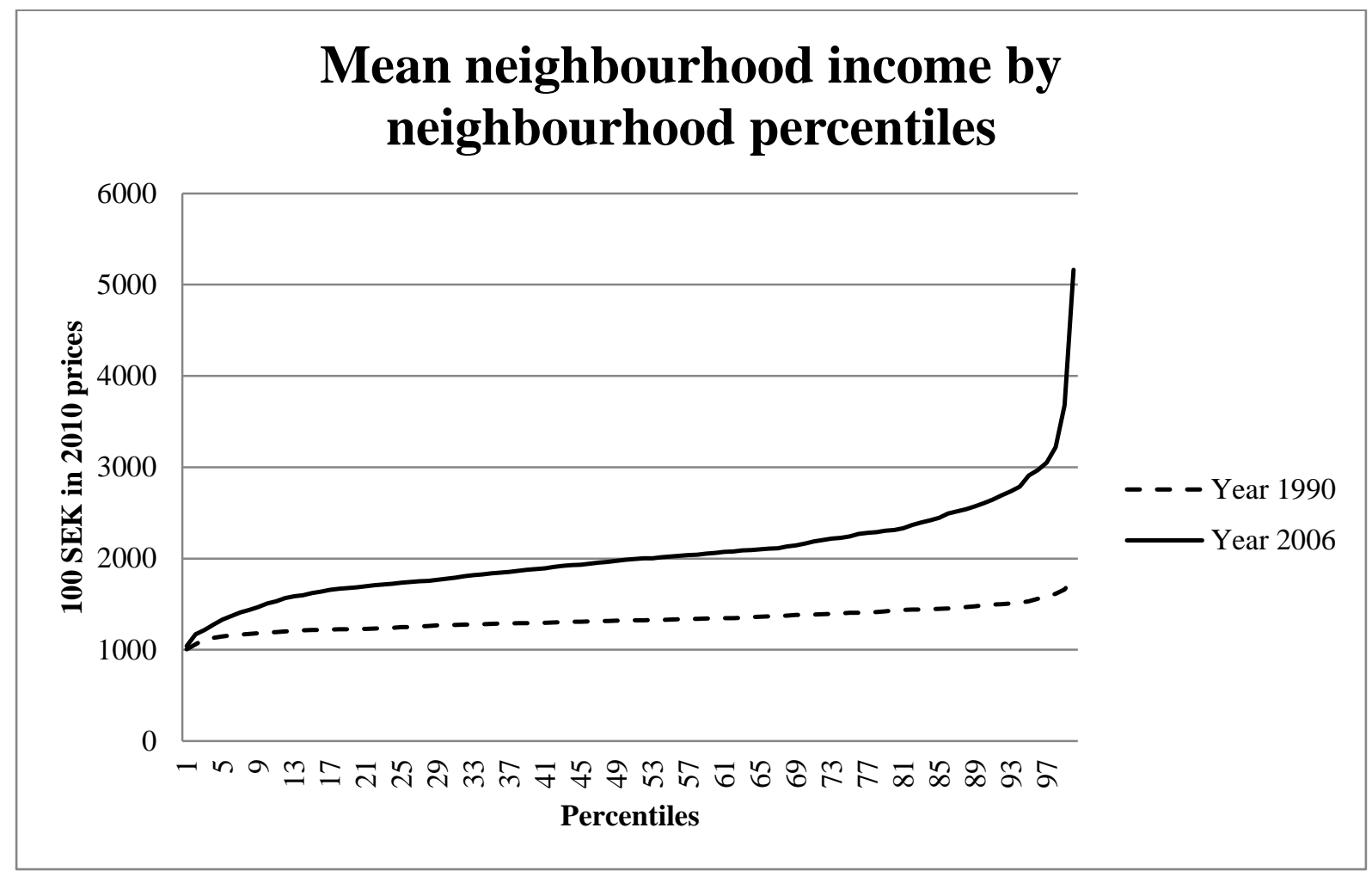




\section{Table 1}

\section{Descriptive statistics}

\begin{tabular}{|c|c|c|c|c|c|c|}
\hline Variable & All & & Majority & & $\begin{array}{l}\text { Visible } \\
\text { minority }\end{array}$ & \\
\hline & Mean & std & Mean & std & Mean & std \\
\hline $\begin{array}{l}\text { Neighbourhood mean disposable income } \\
\text { in } 2006\end{array}$ & 209731 & 57347 & 212306 & 57420 & 180077 & 47298 \\
\hline $\begin{array}{l}\text { Neighbourhood mean disposable income } \\
\text { in } 1990\end{array}$ & 134445 & 13325 & 135460 & 12862 & 122756 & 12990 \\
\hline $\begin{array}{l}\text { Neighbourhood mean disposable income } \\
\text { in } 2006 \text {, if same neighbourhood as in } 1990\end{array}$ & 207643 & 61425 & 211748 & 61064 & 160393 & 43096 \\
\hline Household disposable income in 1990 & 117099 & 55939 & 119939 & 56834 & 84402 & 28391 \\
\hline Household disposable income in 2006 & 169363 & 147086 & 172452 & 150346 & 133795 & 95398 \\
\hline $\begin{array}{l}\text { Logarithm of neighbourhood mean } \\
\text { disposable income in } 2006\end{array}$ & 7.62 & 0.23 & 7.63 & 0.22 & 7.46 & 0.25 \\
\hline $\begin{array}{l}\text { Logarithm of neighbourhood mean } \\
\text { disposable income in } 1990\end{array}$ & 7.20 & 0.10 & 7.21 & 0.09 & 7.11 & 0.11 \\
\hline $\begin{array}{l}\text { Logarithm of household disposable } \\
\text { income in } 1990\end{array}$ & 7.00 & 0.36 & 7.03 & 0.34 & 6.67 & 0.41 \\
\hline $\begin{array}{l}\text { Logarithm of household disposable } \\
\text { income in } 2006\end{array}$ & 7.25 & 0.65 & 7.27 & 0.64 & 7.00 & 0.71 \\
\hline $\begin{array}{l}\text { Logarithm of neighbourhood mean } \\
\text { disposable income in } 2006 \text {, if same } \\
\text { neighbourhood as in } 1990\end{array}$ & 7.60 & 0.26 & 7.63 & 0.24 & 7.35 & 0.24 \\
\hline $\begin{array}{l}\text { Living in the same neighbourhood in } 1990 \\
\text { and } 2006\end{array}$ & 0.17 & 0.38 & 0.16 & 0.37 & 0.26 & 0.44 \\
\hline
\end{tabular}

Source: Authors' calculations from LISA with neighbourhood definitions added

*PBB=Price base amount (about 42400 SEK in 2010)

Note: Disposable income is measured in constant (2010) prices. 
Table 2

Intergenerational income elasticities and correlations

\begin{tabular}{|c|c|c|c|c|c|c|c|}
\hline & Intercept & std & $\begin{array}{l}\text { Regression } \\
\text { coefficients }\end{array}$ & std & $\mathbf{R}^{2}$ & $\begin{array}{l}\text { Correlation } \\
\text { coefficients }\end{array}$ & $\begin{array}{l}\text { Number of } \\
\text { observatio } \\
\text { ns }\end{array}$ \\
\hline \multicolumn{8}{|c|}{ Neighbourhood disposable income } \\
\hline All & $0.236^{*}$ & 0.107 & $1.026 * * *$ & 0.015 & 0.197 & $0.444 * * *$ & 19445 \\
\hline Majority & $0.617 * * *$ & 0.116 & $0.974 * * *$ & 0.016 & 0.171 & $0.413 * * *$ & 17891 \\
\hline Visible minority & 0.701 & 0.384 & $0.952 * * *$ & 0.054 & 0.166 & $0.408 * * *$ & 1554 \\
\hline \multicolumn{8}{|c|}{ Household disposable income } \\
\hline All & $5.566 * * *$ & 0.090 & $0.240 * * *$ & 0.013 & 0.018 & $0.133 * * *$ & 19445 \\
\hline Majority & $5.921 * * *$ & 0.099 & $0.192 * * *$ & 0.014 & 0.010 & $0.102 * * *$ & 17891 \\
\hline Visible minority & $5.348 * * *$ & 0.290 & $0.247 * * *$ & 0.043 & 0.020 & $0.143 * * *$ & 1554 \\
\hline \multicolumn{8}{|c|}{$\begin{array}{l}\text { Simulation assuming that all individuals lived in the same neighbourhood } 2006 \text { as in } \\
1990\end{array}$} \\
\hline All & $-9.197 * * *$ & 0.058 & $2.334 * * *$ & 0.008 & 0.809 & $0.899 * * *$ & 19445 \\
\hline Majority & $-9.062 * * *$ & 0.065 & $2.316 * * *$ & 0.009 & 0.788 & $0.888 * * *$ & 17891 \\
\hline Visible minority & $-7.850 * * *$ & 0.151 & $2.139 * * *$ & 0.021 & 0.867 & $0.931 * * *$ & 1554 \\
\hline \multicolumn{8}{|c|}{ Estimates based on the subset of those who have changed neighbourhood } \\
\hline All & $1.886^{* * *}$ & 0.119 & $0.798 * * *$ & 0.016 & 0.126 & $0.354 * * *$ & 16431 \\
\hline Majority & $2.081 * * *$ & 0.128 & $0.771 * * *$ & 0.018 & 0.111 & $0.333 * * *$ & 15151 \\
\hline Visible minority & $2.798 * * *$ & 0.441 & $0.663 * * *$ & 0.062 & 0.087 & $0.296 * * *$ & 1190 \\
\hline
\end{tabular}

Source: Authors' estimates from LISA with neighbourhood definitions added. $* * * \mathrm{p}<0.01$ 
Table 3

Percentage living in a certain neighbourhood quartile as an adult, given the neighbourhood quartile as a teenager. Row percentages.

\section{DESTINATION QUARTILES}

\begin{tabular}{cccccc}
\hline ORIGIN QUARTILES & & & & & \\
Visible minorities & Bottom & Second & Third & Top & $\begin{array}{l}\text { Number of } \\
\text { observations }\end{array}$ \\
Bottom & 61 & 17 & 14 & 8 & 876 \\
Second & 39 & 27 & 19 & 15 & 364 \\
Third & 24 & 22 & 37 & 17 & 188 \\
Top & 22 & 15 & 17 & 46 & 126 \\
& & & & & \\
Majority & Bottom & Second & Third & Top & \\
Bottom & 35 & 31 & 22 & 12 & 3463 \\
Second & 22 & 34 & 27 & 17 & 4125 \\
Third & 15 & 24 & 36 & 26 & 4392 \\
Top & 8 & 14 & 29 & 49 & 5911 \\
\hline
\end{tabular}

Mean neighbourhood income in different quartiles in 2010 prices (standard errors in brackets)

\begin{tabular}{lll}
\hline Quartiles & $\begin{array}{l}\text { Mean neighbourhood income } \\
\text { per individual }\end{array}$ & $\begin{array}{l}\text { Mean neighbourhood income } \\
\text { per individual }\end{array}$ \\
\cline { 2 - 3 } & 1990 & 2006 \\
$\mathbf{1}$ & $117890(6402)$ & $154715(16932)$ \\
$\mathbf{2}$ & $128727(1993)$ & $185977(7170)$ \\
$\mathbf{3}$ & $135878(2470)$ & $209354(7481)$ \\
$\mathbf{4}$ & $149508(9225)$ & $271967(71120)$ \\
\hline
\end{tabular}

Source: Authors' calculations from LISA with neighbourhood definitions added. 
Table 4.

Percentage living in a given neighbourhood quartile as child and adult. Cell percentages.

\begin{tabular}{cllll}
\hline & & \multicolumn{4}{l}{ DESTINATION QUARTILES } \\
\hline ORIGIN QUARTILES & & Second & Third & Top \\
Visible minorities & Bottom & 10 & 8 & 5 \\
Bottom & 34 & 6 & 4 & 3 \\
Second & 9 & 3 & 5 & 2 \\
Third & 3 & 1 & 1 & 4 \\
Top & 2 & & & \\
& & Second & Third & Top \\
Majority & Bottom & 6 & 4 & 2 \\
Bottom & 7 & 8 & 6 & 4 \\
Second & 5 & 6 & 9 & 6 \\
Third & 4 & 5 & 10 & 16 \\
Top & 3 & & & \\
\hline
\end{tabular}

Source: Authors' calculations from LISA with neighbourhood definitions added. 
Table 5

The persistence of extreme advantage and disadvantage in Sweden and the US Sweden United States

\begin{tabular}{lllll}
\hline & Visible & Majority & Black & White \\
minorities & &
\end{tabular}

At the bottom:

Per cent remaining in poorest decile $\quad 48$

22
48

Per cent in poorest decile in each generation

19

2

25

19

At the top:

Per cent remaining in most affluent decile

32

32

N/A

45

Per cent in most affluent decile in each 1

4

N/A

5

generation 